\title{
Mercury, cadmium, and lead in cigarettes from international markets: concentrations, distributions and absorption ability of filters
}

\author{
Quang Phan Dinh'1,3, Randy Novirsa', Huiho Jeong1', Willy Cahya Nugraha1, \\ Sylvester Addai-Arhin ${ }^{1}$, Pham Hung Viet ${ }^{3}$, Nobuaki Tominaga ${ }^{4}$, Yasuhiro Ishibashi \\ and Koji Arizono ${ }^{2}$ \\ ${ }^{\prime}$ Graduate School of Environmental and Symbiotic Sciences, Prefectural University of Kumamoto, \\ 3-1-100, Tsukide, Higashi-ku, Kumamoto 862-8502, Japan \\ ${ }^{2}$ Faculty of Environmental and Symbiotic Sciences, Prefectural University of Kumamoto, \\ 3-1-100, Tsukide, Higashi-ku, Kumamoto 862-8502, Japan \\ ${ }^{3} \mathrm{VNU}$ University of Science, Vietnam National University, Hanoi, \\ 334 Nguyen Trai, Thanh Xuan, Hanoi, Vietnam \\ ${ }^{4}$ Department of Creative Engineering, National Institute of Technology, Ariake College, \\ 150 Higashihagio-chou, Omuta-shi, Fukuoka 836-8585, Japan
}

(Received March 10, 2021; Accepted June 2, 2021)

\begin{abstract}
Mercury $(\mathrm{Hg})$, cadmium $(\mathrm{Cd})$, and lead $(\mathrm{Pb})$ concentrations in marketed cigarettes from South Korea, Vietnam, Japan, Indonesia, Taiwan, Thailand, the United Kingdom (UK), Belgium, Italy, Finland, and France were investigated. The cigarettes from Vietnam and Thailand had the highest trend of $\mathrm{Hg}$. Meanwhile, $\mathrm{Cd}$ was found higher in cigarettes from Thailand, the UK, and Belgium. Pb concentrations in cigarettes from Belgium, the UK, and Korea were higher than others. The average of these heavy metals concentrated in cigarettes was in the order of $\mathrm{Pb}>\mathrm{Cd}>\mathrm{Hg}$. Furthermore, the contents of these heavy metals in cigarette leaves were much higher than in filter and rolling paper. There was a significant positive correlation between $\mathrm{Hg}$ and $\mathrm{Cd}$, but no correlation between $\mathrm{Cd}$ and $\mathrm{Pb}$ and between $\mathrm{Hg}$ and $\mathrm{Pb}$. Significant positive correlations of nicotine with $\mathrm{Hg}$ and $\mathrm{Cd}$ but not $\mathrm{Pb}$ in the cigarette were observed. Activated carbon filters $(\mathrm{Ce}-\mathrm{C})$ absorb $\mathrm{Cd}$ and $\mathrm{Pb}$ from cigarette leaves and rolling paper indicated a higher trapping trend than cellulose acetate filter without activated carbon $(\mathrm{Ce})$. The trapping ratios of Ce-C (Cd: $5.53 \%, \mathrm{~Pb}: 5.41 \%)$ were higher than $\mathrm{Ce}(\mathrm{Cd}: 3.09 \%, \mathrm{~Pb}: 5.49 \%)$. On the other hand, $\mathrm{Hg}$ had lower absorption by both types of filters (Ce: $0.15 \%, \mathrm{Ce}-\mathrm{C}: 0.02 \%$ ). This revealed that $\mathrm{Hg}, \mathrm{Cd}$ and $\mathrm{Pb}$ absorption ability by both filters was relatively lower to the total concentration of these metals in tobacco leaves and rolling paper. The concern was that the higher concentrations of metals such as $\mathrm{Hg}, \mathrm{Cd}$ and $\mathrm{Pb}$ in cigarettes might exist in mainstream smoke.
\end{abstract}

Key words: Cigarettes, Distribution, Heavy metals, Mercury, Cadmium, Lead

\section{INTRODUCTION}

Tobacco has been used in the world for thousands of years by humans. Tobacco and its smoke contain more than 4000 different substances, including various carcinogens and toxic metals (Stration et al., 2001). As a crop, tobacco is considered an indicator of environmental pollution. Air pollutants damage food crops' yield and nutritional quality and safety, imposing a major risk to food safety. In addition to this, the soil parent material is the most important influencing factor of heavy metal concentrations, and human activities are the main external sources of heavy metals (Wu et al., 2020). Around 6.5 trillion cigarettes are sold worldwide each year, which translates to roughly 18 billion cigarettes per day (Martin, 2019). Furthermore, tobacco kills more than 8 million people each year. More than 7 million deaths result from direct tobacco use, while around 1.2 million result from non-smokers being exposed to secondhand smoke (World Health Organization, 2019). In particu-

Correspondence: Koji Arizono (E-mail: arizono@pu-kumamoto.ac.jp) 
lar, tobacco is strongly identified as a source of cadmium (Cd) exposure in humans. Humans are also exposed to lead $(\mathrm{Pb})$ vapors through inhalation. $\mathrm{Pb}$ from cigarette smoke (including second and third-hand tobacco smoke exposures) may increase blood $\mathrm{Pb}$ levels in children (Agency for Toxic Substances and Disease Registry, 2019). The research data on mercury $(\mathrm{Hg})$ in the cigarette is still limited; meanwhile, the effect of $\mathrm{Hg}$ on human health has been known to mainly affect the nervous system, seriously affecting the fetus if exposed to mercury from the mother. Therefore, a study investigating $\mathrm{Hg}$, $\mathrm{Cd}$, and $\mathrm{Pb}$ concentrations in commercial cigarettes from many regions and countries is needed. These data will contribute to the management and prevention of tobaccorelated harms to the community and human health.

Recently, several studies on heavy metals in tobacco have been implemented. Ziarati et al. (2017) indicated that $\mathrm{Cd}$ and $\mathrm{Pb}$ are found in cigarette tobacco, showing that the tobacco plant easily takes up metals from soil and concentrates them in leaves. This report published that the ratios of $\mathrm{Cd}$ and $\mathrm{Pb}$ absorbed and trapped by filters were $116-234 \%$ and $112-198 \%$. From these results, the cigarette filters had very high absorbing abilities of $\mathrm{Cd}$ and $\mathrm{Pb}$ by cigarette filter, even higher than $100 \%$. In other research, an extensive investigation of 42 elements, including trace elements in the blood of non-smokers, cigarette smokers, and e-cigarettes users, was implemented and this showed that the content of elements in cigarette smokers had the highest concentrations of copper $(\mathrm{Cu})$, molybdenum $(\mathrm{Mo})$, zinc $(\mathrm{Zn})$, antimony $(\mathrm{Ab})$, and strontium. The e-cigarette users presented the highest levels of selenium (Se), silver (Ag), and vanadium (V) (Badea et al., 2018). These studies showed that cigarette smoke might be an important source of metal exposure in humans. Yurdakök, (2015) recommended that research on $\mathrm{Pb}$, $\mathrm{Hg}$, and $\mathrm{Cd}$ in breast milk should aim to reduce life-long exposure through precautionary measures such as prevention of exposure to cigarette smoke, use of unleaded gasoline, and prevention of air pollution with an effect at the community level. Artisanal and small-scale gold mining is known to be the major anthropogenic source of $\mathrm{Hg}$ pollution globally due to the direct use of $\mathrm{Hg}$ in the gold mining processes (Norvisa et al., 2019; Addai-Arhin et al., 2021). Besides, the improper management of factories or equipment containing mercury also leads to Hg leakage into the environment that is toxic to humans and the ecosystem (Bai et al., 2017; United Nations Environment, 2019). Hg is volatile even at room temperature, making it a global pollutant. Kowalski and Wiercinski (2009) reported that $\mathrm{Hg}$ was found in tobacco cigarettes and ranged from 2.95-10.2 ng Hg per single cigarette. Almost all mercury contained was released into the smoke (from 86.7 to $100 \%)$. However, they used a "mechanical lip" model to determine the mercury concentration in cigarette smoke. Airflow interruption by balancing the pump valve connected to the pump syringe leads $\mathrm{Hg}$ separately to mainstream and side-stream smoke. Therefore, the absorption of mercury by the filter had not been fully evaluated. Heavy metal analysis in cigarette smoke is still hampered by the loss of smoke flow and smoking process descriptors' entanglement. Tobacco smoke analysis is also susceptible to cross-contamination of samples when conducting experiments. Therefore, this affects test results and is difficult to perform on many samples.

Thus, the aims of this study were to first (1) investigate concentrations of heavy metals, including $\mathrm{Hg}, \mathrm{Cd}$, and $\mathrm{Pb}$, in marketed cigarettes collected from retail sale stores in several countries, including South Korea (Korea), Japan, Taiwan, Thailand, Vietnam, Belgium, France, Italy, Finland, and the United Kingdom (UK), and second, (2) analyze the distribution concentrations of $\mathrm{Hg}, \mathrm{Cd}$, and $\mathrm{Pb}$ in parts of the cigarette (cigarette filter, tobacco, and rolling paper). The correlations of nicotine concentration with $\mathrm{Hg}, \mathrm{Cd}$, and $\mathrm{Pb}$ in tobacco also were discussed. Furthermore, the absorption ability of $\mathrm{Hg}, \mathrm{Cd}$, and $\mathrm{Pb}$ from tobacco after smoking by filter materials was observed. Through that, we assessed the transfer of these heavy metals from cigarette to smoke.

\section{MATERIALS AND METHODS}

\section{Sampling and pretreatment}

Sixty-seven samples of marketed cigarettes were collected from convenience stores in several countries in the world through 2019. In Asia, 52 cigarette samples were collected (Korea: $n=10$, Vietnam: $n=9$, Japan: $n=10$, Indonesia: $n=13$, Thailand: $n=4$, and Taiwan: $n=6$ ) while 15 samples were collected from Europe (Belgium: $n=3$, France: $n=3$, Italy: $n=3$, Finland: $n=3$, and the UK: $n=3$ ). In each country, the samples were collected from different brands of cigarettes. There were several cigarette brands of the same brand but that were collected from different countries. However, information from the cigarette labels indicated that the manufacturers were in the cigarette home country. The label claims of nicotine concentration in the cigarette were recorded. Cigarette samples were dried at room temperature for two days, then homogenized using mortar and pestle. The homogenized cigarette samples were packaged in polypropylene tubes and kept at $4^{\circ} \mathrm{C}$ in a refrigerator until analysis.

To comprehend $\mathrm{Hg}, \mathrm{Cd}$, and $\mathrm{Pb}$ 's fate in parts of a cig- 
Levels of some heavy metals in cigarettes from international markets

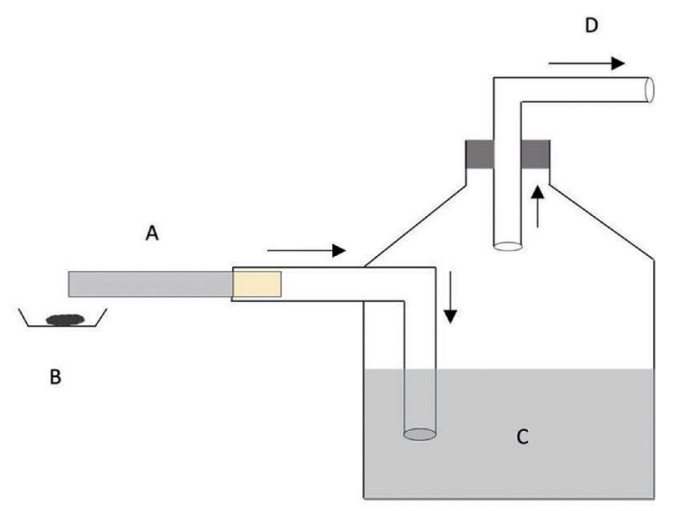

Fig. 1. Model of smoking. A - cigarette, B - sample boat for ash accumulation, C - water scrubber, D - pump.

arette after smoking, we conducted an analysis of these heavy metals in filters and the ash after smoking, using a physical model of smoking (Fig. 1). In this case, a rubber tube was connected to the filter of the cigarette. The pump was run non-stop, the tobacco was burned until finished to keep all the smoke through the filter. Therefore, this experiment conducted a survey only in the mainstream smoke to estimate tobacco's transfer abilities to smoke.

\section{Mercury, cadmium, and lead analysis methods Mercury analysis method}

Approximately $50 \mathrm{mg}$ sample was weighed using an analytical/electronic balance (Practum124-1SJP, Satorius, Göttingen, Germany). Hg was determined using pyrolysis atomic absorption spectrometry with gold amalgamation by a model of mercury analyzer 3000 (Nippon Instrument Corporation, Tokyo, Japan). Hg was determined at a wavelength of $253.7 \mathrm{~nm}$ by thermal combustion. The oxygen gas was purchased from Kumamoto Sanso Corporation (Kumamoto, Japan), and the flowing gas was set at $0.2 \mathrm{~L} / \mathrm{min}$. Two calibration curves were prepared using a $\mathrm{Hg}$ standard solution $(1000 \mathrm{mg} / \mathrm{L}$, Wako Pure Chemical Company, Osaka, Japan), to calculate $\mathrm{Hg}$ concentration in samples. The low calibration curves were prepared at six points of $0.2,0.5,1,5,10$, and $20 \mathrm{ng} \mathrm{Hg}$, and the high calibration curves were prepared at six points of 10,20,50,100,200, and $500 \mathrm{ng}$ of $\mathrm{Hg}$. The calibration curves were described based on the real $\mathrm{Hg}$ concentration of analysis with the area of absorbance (ABS) from the atomic absorption spectroscopy of a mercury analyzer (MA 3000, NIC, Tokyo, Japan). The correlation coefficients were 0.9999 for both calibration curves at high and low $\mathrm{Hg}$ concentrations. The method limit of detection (MDL) was calculated using the formula: 3SD of a blank sample $(n=20)$, while the method limit of quantification (MQL) was calculated using 10SD. The MDL and MQL values for the Hg analysis method in cigarette leaf were informed at $0.03 \mathrm{ng} / \mathrm{g}$ and $0.09 \mathrm{ng} / \mathrm{g}$, respectively.

\section{Cadmium and lead analysis method}

Cadmium and lead concentrations were determined using the method described by Shaheen et al. (2016). Approximately $0.5 \mathrm{~g}$ of cigarette samples were weighed into Teflon vessels, and $6 \mathrm{~mL}$ of $69 \%$ nitric acid $\left(\mathrm{HNO}_{3}\right)$ and $2 \mathrm{~mL}$ of $30 \%$ hydrogen peroxide $\left(\mathrm{H}_{2} \mathrm{O}_{2}\right)$ (Wako Pure Chemical Company) were added. The mixture was digested using a microwave digestion system (Milestone MLS 1200 Mega, Sorisole, Italy). The digested solution was transferred into the volumetric flask and increased to $50 \mathrm{~mL}$ by adding ultrapure water (Barnstead Smart2Pure, ThermoFisher Scientific, Waltham, MA, USA). The solution was filtered using a membrane filter (DISMIC ${ }^{\circledR}$-25HP PTFE, $0.45 \mu \mathrm{m}$, Toyo Roshi, Tokyo, Japan) and stored in $50 \mathrm{~mL}$ polypropylene tubes at $4^{\circ} \mathrm{C}$ until analysis.

$\mathrm{Cd}$ and $\mathrm{Pb}$ in the digested solution were determined using graphite furnace atomic absorption spectroscopy GF-AAS Z-2700 (Hitachi High-Technologies Corporation, Tokyo, Japan) at wavelengths of $228.8 \mathrm{~nm}$ and $283.3 \mathrm{~nm}$, respectively. Approximately $10 \mu \mathrm{L}$ digested solution was automatically injected into the pyro tube HR (Hitachi High-Technologies Corporation). Then, 10 $\mu \mathrm{L}$ of Palladium Magnesium solution used as Matrix Modifier (Hitachi High-Technologies Corporation) was added to the pyro tube. The pyro graphite tube temperature for $\mathrm{Cd}$ and $\mathrm{Pb}$ atomization was set at $1500^{\circ} \mathrm{C}$ and $2000^{\circ} \mathrm{C}$, respectively. The argon gas was purchased from Kumamoto Sanso Corporation, and the flow gas was set at $200 \mathrm{~mL} / \mathrm{min}$. The calibration curves for $\mathrm{Cd}$ and $\mathrm{Pb}$ were obtained at standard concentrations of $0 ; 0.2 ; 0.5$; $1 ; 2$; and $5 \mu \mathrm{g} / \mathrm{L}$ and $0 ; 1 ; 2 ; 5 ; 10$; and $20 \mu \mathrm{g} / \mathrm{L}$, respectively, using multielement standard solution 6 for ICP (Sigma-Aldrich, Postfach 9471, Buchs SG, Switzerland). The correlation coefficients $\left(\mathrm{R}^{2}\right)$ of $\mathrm{Cd}$ and $\mathrm{Pb}$ 's calibration curves were 0.9991 and 0.9994 , respectively. The MDL and MQL for the method of analysis Cd in cigarette leaf were informed at $0.02 \mathrm{ng} / \mathrm{g}$ and $0.06 \mathrm{ng} / \mathrm{g}$, respectively. Furthermore, the MDL and MQL for the analysis method of $\mathrm{Pb}$ were $0.09 \mathrm{ng} / \mathrm{g}$ and $0.28 \mathrm{ng} / \mathrm{g}$, respectively.

\section{Quality assurance and control}

Reagents and experiment tools were under tight control and avoided cross-contamination. All reagents used 
were of analytical grade and of highest purity. All experiment tools needed to be cleaned before use. In detail, in the $\mathrm{Cd}$ and $\mathrm{Pb}$ analysis, before use the experiment tools were washed with tap water, kept in $\mathrm{HNO}_{3} 5 \%$ overnight, and washed one more time by ultrapure water. Then, the tools were dried for $4 \mathrm{hr}$ using a drier oven. For $\mathrm{Hg}$, after cleaning by soap and ultrapure water, sample boats were kept in a furnace for $5 \mathrm{hr}$ at $750^{\circ} \mathrm{C}$ to remove remaining $\mathrm{Hg}$. The pyro graphite tube used to analyze $\mathrm{Cd}$ and $\mathrm{Pb}$ was cleaned at $1800^{\circ} \mathrm{C}$ and $2200^{\circ} \mathrm{C}$ after sample atomization in the furnace graphite AAS system after each analysis. The accuracy and precision of analyses were validated by measuring the $\mathrm{Hg}, \mathrm{Cd}$, and $\mathrm{Pb}$ in triplicate of the subsample, blank samples, and before and after each group of nine samples measurement. The $\mathrm{Hg}, \mathrm{Cd}$, and $\mathrm{Pb}$ spiked samples were analyzed together with real samples, the recoveries of $\mathrm{Hg}, \mathrm{Cd}$, and $\mathrm{Pb}$ were confirmed to range from $91 \%$ to $105 \%$.

\section{Statistical analysis}

Statistical analysis was carried out using IBM $^{\circledR}$ SPSS $^{\circledR}$ Statistics Version 26 (IBM Corporation, New York, NY, USA). In these, all correlation comparisons used Spearman's correlation test (two-tailed). The differences in the mean content of the same metal in the same filter materials of the cigarettes before and after smoking were compared using paired sample t-test (two-tailed). The differences in the mean content of the same metal in different filter materials of cigarettes before and after smoking were also compared using an independent samples t-test (two-tailed).

\section{RESULTS AND DISCUSSION}

\section{Cigarette properties}

The filtered cigarette is made from three main parts: cigarette filter, roll paper, and tobacco. According to our investigation, in the markets, some brands did not have a filter. However, all collected samples contained a filter. There was an average $0.829 \pm 0.129 \mathrm{~g} /$ cigarette (tobacco leaf: $0.633 \pm 0.098 \mathrm{~g}$ /cigarette; filter: $0.158 \pm$ $0.050 \mathrm{~g} /$ cigarette; and roll paper: $0.038 \pm 0.006 \mathrm{~g} /$ cigarette). Tobacco accounted for $76.36 \%$ of the total weight of the whole cigarette on average. Filters and rolling paper accounted for $19.06 \%$ and $4.58 \%$ of one filtered cigarette's total weight, respectively. The nicotine concentration in cigarettes was taken from the package label of the cigarette. The cigarettes that were collected from Korea, Japan, Taiwan, and Indonesia had nicotine concentration indicated on the package label. In contrast, those bought from Vietnam, Thailand, the UK, Belgium, Fin- land, and France did not indicate nicotine concentration. According to the label's information, the average nicotine concentration in cigarettes collected from these countries was $0.78 \pm 0.6 \mathrm{mg} /$ cigarette $(0.1-2.3 \mathrm{mg} /$ cigarette) . The average nicotine concentrations in the cigarettes were in the order: Korea (nicotine: $0.31 \pm 0.18 \mathrm{mg} /$ cigarette) $<$ Japan $(0.54 \pm 0.25 \mathrm{mg} /$ cigarette $)<$ Taiwan $(0.56 \pm 0.21$ $\mathrm{mg} /$ cigarette $)<$ Indonesia $(1.54 \pm 0.49 \mathrm{mg} /$ cigarette $)$. These results showed that the smoker habit of the cigarette with nicotine concentrations was different in each country. The cigarettes collected from Indonesia had a higher dose of nicotine than other countries, indicating a preference for smoking with high nicotine doses in Indonesian smokers. Korean cigarettes had relatively low nicotine levels in the region, whereas Japan and Taiwan have slightly higher levels of this ingredient in cigarettes. Nicotine is highly addictive and is made by several types of plants such as Nicotiana tabacum and is also produced synthetically (Holbrook, 2016; Siqueira et al., 2017). It can cause an increase in blood pressure, heart rate, blood flow to the heart, and a narrowing of the arteries (vessels that carry blood). Smokers who tend to use nicotine levels to increase pleasure after smoking means an increase in tar levels in cigarettes. This puts them at increased risk of adverse health effects due to nicotine, particularly in cigarettes and tobacco in general.

\section{The distribution of mercury, cadmium, and lead in cigarette}

Based on the experiment layout, after smoking, the cigarette left ash, smoke, and filter. Thus, we supposed that $\mathrm{Hg}, \mathrm{Cd}$, and $\mathrm{Pb}$ from tobacco leaves and rolling paper go to three pathways: to be trapped by filter, to remain in the ash, and to transfer to smoke. Therefore, we estimated the ratio of $\mathrm{Hg}, \mathrm{Cd}$, and $\mathrm{Pb}$ from one cigarette to smoke after smoking.

The distribution of $\mathrm{Hg}, \mathrm{Cd}$, and $\mathrm{Pb}$ concentrations in parts of cigarettes is shown in Table 1. The mean concentrations of $\mathrm{Hg}, \mathrm{Cd}$, and $\mathrm{Pb}$ in tobacco of cigarette samples were $19.95 \pm 4.8 \mathrm{ng} / \mathrm{g}, 1.34 \pm 0.59 \mu \mathrm{g} / \mathrm{g}$, and $2.30 \pm 2.64 \mu \mathrm{g} / \mathrm{g}$, respectively. The filter contained mean concentrations of $0.13 \pm 0.13 \mathrm{ng} / \mathrm{g}, 0.04 \pm 0.05 \mu \mathrm{g} / \mathrm{g}$, and $0.05 \pm 0.07 \mu \mathrm{g} / \mathrm{g}$ of $\mathrm{Hg}, \mathrm{Cd}$, and $\mathrm{Pb}$, respectively. For rolling paper, $\mathrm{Hg}$ was not detected $(<\mathrm{MDL})$, while mean concentrations of $\mathrm{Cd}$ and $\mathrm{Pb}$ were $0.08 \pm 0.11 \mu \mathrm{g} / \mathrm{g}$ and $0.26 \pm 0.24 \mu \mathrm{g} / \mathrm{g}$, respectively. The results showed that $\mathrm{Hg}, \mathrm{Cd}$, and $\mathrm{Pb}$ in cigarettes are mostly contained in tobacco leaf. As discussed above, tobacco accounted for an average of $76.36 \%$ of the total weight of the whole cigarette, indicating that these heavy metals in cigarettes mainly come from tobacco. In addition, tobac- 
Levels of some heavy metals in cigarettes from international markets

Table 1. Comparison of $\mathrm{Hg}, \mathrm{Cd}$, and $\mathrm{Pb}$ in parts of cigarette.

\begin{tabular}{lcccccc}
\hline \multirow{2}{*}{ Part of cigarette } & \multicolumn{3}{c}{ Before smoking $($ Mean $\pm \mathrm{SD})$} & \multicolumn{3}{c}{ After smoking $(\mathrm{Mean} \pm \mathrm{SD})$} \\
\cline { 2 - 7 } & $\mathrm{Hg}(\mathrm{ng} / \mathrm{g})$ & $\mathrm{Cd}(\mu \mathrm{g} / \mathrm{g})$ & $\mathrm{Pb}(\mu \mathrm{g} / \mathrm{g})$ & $\mathrm{Hg}(\mathrm{ng} / \mathrm{g})$ & $\mathrm{Cd}(\mu \mathrm{g} / \mathrm{g})$ & $\mathrm{Pb}(\mu \mathrm{g} / \mathrm{g})$ \\
\hline Tobacco leaves & $19.95 \pm 4.8$ & $1.34 \pm 0.59$ & $2.30 \pm 2.64$ & $\mathrm{NA}$ & $\mathrm{NA}$ & $\mathrm{NA}$ \\
Paper & $<\mathrm{MDL}$ & $0.08 \pm 0.11$ & $0.25 \pm 0.24$ & $\mathrm{NA}$ & $\mathrm{NA}$ & $\mathrm{NA}$ \\
Ash & $\mathrm{NA}$ & $\mathrm{NA}$ & $\mathrm{NA}$ & $<\mathrm{MDL}$ & $0.62 \pm 0.42$ & $<\mathrm{MDL}$ \\
Filter & $0.13 \pm 0.13$ & $0.04 \pm 0.04$ & $0.04 \pm 0.07$ & $0.26 \pm 0.24$ & $0.35 \pm 0.25$ & $0.97 \pm 0.92$ \\
\hline
\end{tabular}

$<$ MDL: below method detection limit, NA: not available.

co is made from the leaf of the tobacco plant (Nicotiana tabacum). These heavy metals are absorbed from the soil by the plant's roots and transported to the leaf. However, the percentage concentrations of $\mathrm{Hg}, \mathrm{Cd}$, and $\mathrm{Pb}$ in cigarette paper and filters are relatively lower. Toxic heavy metals are the major source of environmental pollution in this new millennium. $\mathrm{Hg}, \mathrm{Cd}$, and $\mathrm{Pb}$ are the most common toxic heavy metals in the environment (Yurdakök, 2015). This explains the presence of these heavy metals in cigarette rolling papers and filters at low concentrations.

As discussed above, $\mathrm{Hg}, \mathrm{Cd}$, and $\mathrm{Pb}$ are mostly contained in tobacco at different concentrations. The concentrations of $\mathrm{Hg}, \mathrm{Cd}$, and $\mathrm{Pb}$ in tobacco are shown in Fig. 2. The result showed that these heavy metals in tobacco occur in the order of $\mathrm{Pb}>\mathrm{Cd}>\mathrm{Hg}$. In all sam- ples, the concentration of $\mathrm{Hg}$ was much lower than $\mathrm{Cd}$ and $\mathrm{Pb}$. The cigarette samples collected from Korea, Vietnam, Indonesia, the UK, and Belgium contained a higher amount of $\mathrm{Pb}$ than $\mathrm{Cd}$. However, $\mathrm{Cd}$ concentration was higher than $\mathrm{Pb}$ in cigarette samples collected from Japan, Taiwan, Thailand, Italy, Finland, and France. The results showed that $\mathrm{Hg}, \mathrm{Cd}$, and $\mathrm{Pb}$ concentrations in tobacco cigarettes from these countries are non-uniformly distributed. For $\mathrm{Cd}$, the highest concentrations in tobacco of cigarettes were found in cigarettes from Thailand $(2.48 \pm 0.96 \mu \mathrm{g} / \mathrm{g})$, the UK $(1.96$ $\pm 0.82 \mu \mathrm{g} / \mathrm{g})$, and Belgium $(1.8 \pm 0.69 \mu \mathrm{g} / \mathrm{g})$. The lowest $\mathrm{Cd}$ concentrations were found in cigarettes from Italy $(0.65 \pm 0.15 \mu \mathrm{g} / \mathrm{g})$, Japan $(0.67 \pm 0.13 \mu \mathrm{g} / \mathrm{g})$, and Indonesia $(0.70 \pm 0.13 \mu \mathrm{g} / \mathrm{g})$. In contrast, the highest concentrations of $\mathrm{Pb}$ in tobacco were in cigarettes from

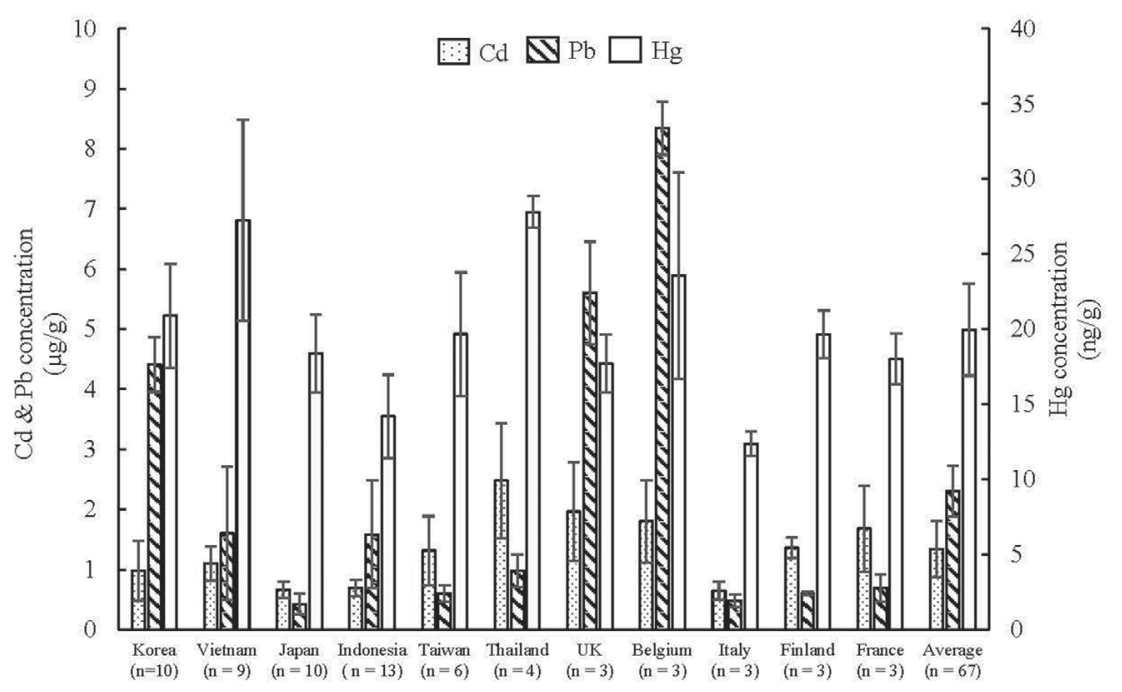

Fig. 2. The concentration of $\mathrm{Hg}, \mathrm{Cd}$, and $\mathrm{Pb}$ in tobacco of cigarettes. The $\mathrm{Cd}$ and $\mathrm{Pb}$ data are shown in the concentration of $\mu \mathrm{g} / \mathrm{g}$ (left vertical axis); the concentration of $\mathrm{Hg}$ is shown in $\mathrm{ng} / \mathrm{g}$ (right vertical axis). Data are represented as Mean $\pm \mathrm{SD}$. 
Belgium $(8.34 \pm 0.44 \mu \mathrm{g} / \mathrm{g})$, the UK $(5.6 \pm 0.86 \mu \mathrm{g} / \mathrm{g})$, and Korea $(4.41 \pm 2.46 \mu \mathrm{g} / \mathrm{g})$. Notably, one cigarette sample from Indonesia had the highest $\mathrm{Pb}$ concentration of $14.5 \mu \mathrm{g} / \mathrm{g}$ ). However, the average $\mathrm{Pb}$ concentration of all cigarettes from Indonesia was $1.58 \pm 3.90 \mu \mathrm{g} / \mathrm{g}$. The cigarettes that were sampled from Japan $(0.43 \pm 0.17 \mu \mathrm{g} / \mathrm{g})$, Taiwan $(0.61 \pm 0.14 \mu \mathrm{g} / \mathrm{g})$, Italy $(0.48 \pm 0.1 \mu \mathrm{g} / \mathrm{g})$, Finland $(0.6 \pm 0.03 \mu \mathrm{g} / \mathrm{g})$, France $(0.69 \pm 0.23 \mu \mathrm{g} / \mathrm{g}) \mathrm{had}$ a low concentration of $\mathrm{Pb}$. In the case of $\mathrm{Hg}$, the results showed that $\mathrm{Hg}$ concentration in tobacco was much lower than $\mathrm{Cd}$ and $\mathrm{Pb}$. The $\mathrm{Hg}$ in tobacco was found at $\mathrm{ppb}$ concentration $(\mathrm{ng} / \mathrm{g})$, while $\mathrm{Cd}$ and $\mathrm{Pb}$ were found at $\mathrm{ppm}$ concentration $(\mu \mathrm{g} / \mathrm{g})$. The highest total $\mathrm{Hg}$ concentration in tobacco was found in cigarettes from Thailand (average: $27.80 \pm 1.06 \mathrm{ng} / \mathrm{g}$ ), Vietnam (average: $27.23 \pm 6.69$ $\mathrm{ng} / \mathrm{g}$ ), Belgium (average: $23.56 \pm 6.88 \mathrm{ng} / \mathrm{g}$ ). $\mathrm{Hg}$ concentrations in tobacco of cigarettes from these countries were higher than those of Korea (average: $20.89 \pm 3.48$ $\mathrm{ng} / \mathrm{g}$ ), Finland (19.66 $\pm 1.58 \mathrm{ng} / \mathrm{g}$ ), Japan (average: 18.38 $\pm 2.6 \mathrm{ng} / \mathrm{g}$ ), France (average: $18.01 \pm 1.68 \mathrm{ng} / \mathrm{g}$ ), and the UK (average: $17.72 \pm 1.92 \mathrm{ng} / \mathrm{g}$ ) who also had similar $\mathrm{Hg}$ concentrations in tobacco of cigarettes. Meanwhile, the $\mathrm{Hg}$ in tobacco of cigarettes from Indonesia (average: $14.19 \pm 2.77 \mathrm{ng} / \mathrm{g})$ and Italy $(12.37 \pm 0.81 \mathrm{ng} / \mathrm{g})$ recorded the lowest concentrations. In this study, the source of tobacco raw material was not investigated. However, it is supposed that the tobacco material from different countries has different $\mathrm{Hg}, \mathrm{Cd}$, and $\mathrm{Pb}$ pollution levels in the environment, such as in the soil, in drainage water, in fer- tilizer used for tobacco cultivation. Regardless of the different concentrations of these metals, their cigarette content is remarkable because these heavy metals in the cigarettes have negative health effects on both primary and secondary smokers following continuous exposure.

Based on $\mathrm{Hg}, \mathrm{Cd}$, and $\mathrm{Pb}$ 's concentration in parts of cigarettes, the amount of $\mathrm{Hg}, \mathrm{Cd}$, and $\mathrm{Pb}$ per one cigarette was also evaluated (Fig. 3). The results showed that the average content of $\mathrm{Hg}, \mathrm{Cd}$, and $\mathrm{Pb}$ per one cigarette was $12.34 \pm 2.77 \mathrm{ng} /$ cigarette, $0.94 \pm 0.38 \mu \mathrm{g} /$ cigarette, and $1.62 \pm 0.74 \mu \mathrm{g} /$ cigarette, respectively. It was realized that the higher the concentration of $\mathrm{Hg}, \mathrm{Cd}$, and $\mathrm{Pb}$ in tobacco of cigarettes and the higher the weight of the cigarette, the greater the concentration of the heavy metals per one cigarette. All the cigarettes contained an amount of tobacco below one gram, the reason that $\mathrm{Hg}, \mathrm{Cd}$, and $\mathrm{Pb}$ levels in a cigarette are lower than their respective evaluated concentrations $(\mu \mathrm{g} / \mathrm{g} ; \mathrm{ng} / \mathrm{g})$. The weight of the cigarette was indicated by the manufacturer on the package label. Generally, the cigarettes from Indonesia had the highest weight of tobacco ( $897.40 \mathrm{mg} /$ cigarette). Also, the $\mathrm{Hg}$, $\mathrm{Cd}$, and $\mathrm{Pb}$ concentrations in tobacco and per one cigarette were the same trends that reflected the distribution of these heavy metals mostly in tobacco of cigarettes.

The correlations between $\mathrm{Hg}, \mathrm{Cd}$, and $\mathrm{Pb}$ are shown in Fig. 4. The results showed a significant correlation between $\mathrm{Hg}$ and $\mathrm{Cd}(r=0.541, p<0.001)$. Meanwhile, the correlations between $\mathrm{Hg}$ and $\mathrm{Pb}$ and between $\mathrm{Cd}$ and $\mathrm{Pb}$ were not significant $(r=0.059$ and 0.095 , respective-

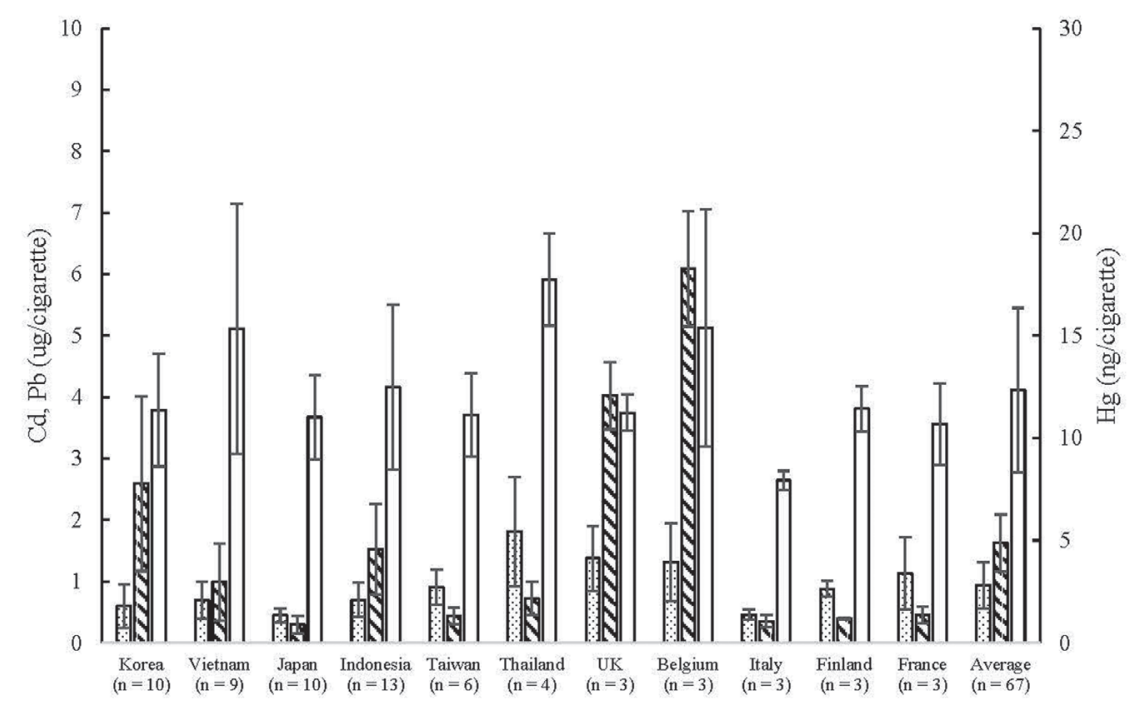

Fig. 3. The concentration of $\mathrm{Hg}, \mathrm{Cd}$, and $\mathrm{Pb}$ in a cigarette. The $\mathrm{Cd}$ and $\mathrm{Pb}$ data are shown in the concentration of $\mu \mathrm{g} / \mathrm{cigarette}$ (left vertical axis); the concentration of $\mathrm{Hg}$ is shown in $\mathrm{ng}$ /cigarette (right vertical axis). Data are represented as Mean $\pm \mathrm{SD}$. 
Levels of some heavy metals in cigarettes from international markets
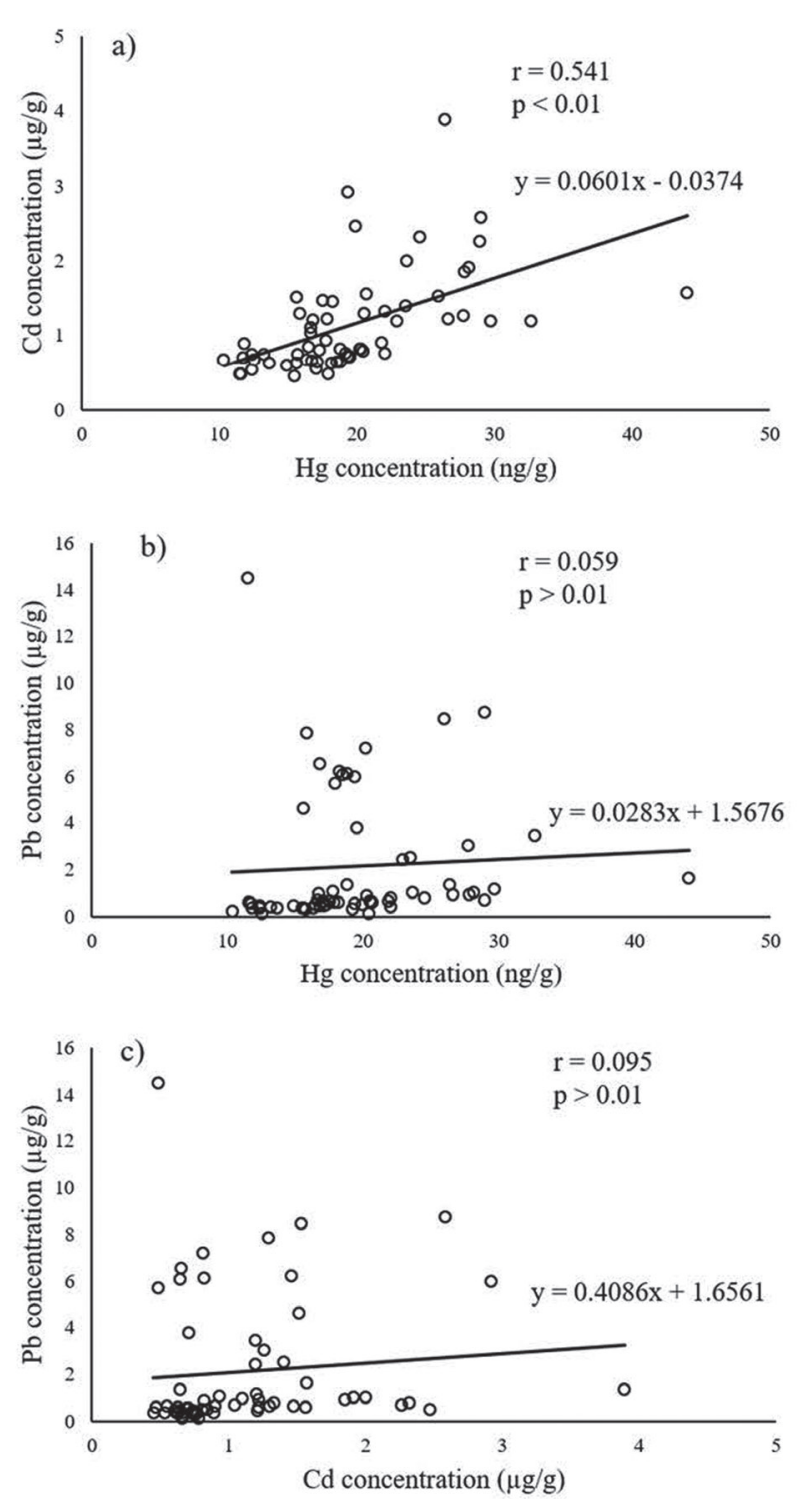

Fig. 4. The correlation of $\mathrm{Cd}, \mathrm{Cd}$, and $\mathrm{Pb}$ concentration in the cigarette. (a: correlation between $\mathrm{Hg}$ and $\mathrm{Cd}$, b: correlation between $\mathrm{Hg}$ and $\mathrm{Pb}$, c: correlation between $\mathrm{Cd}$ and $\mathrm{Pb}$ ).

ly, $p>0.01)$. Although there was no clear correlation between heavy metals in the plant in general, the authors supposed the concentrations of $\mathrm{Hg}, \mathrm{Cd}$, and $\mathrm{Pb}$ in environmental factors such as soil, water, fertilizer can be absorbed by tobacco plants at the same rate if these heavy metals come from the same pollution sources. The correlation between $\mathrm{Hg}$ with $\mathrm{Cd}$ is significant and may have a similar absorption mechanism within the tobacco plant.
Comparison of $\mathrm{Hg}, \mathrm{Cd}$, and $\mathrm{Pb}$ concentration in the cigarettes of the present study with other studies is shown in Table 2. The Hg in marketed cigarettes from some previous studies in the United States of America (Panta et al., 2008; Swani et al., 2009; Fresquez et al., 2015), Canada (Hammond and O'Connor, 2008), and Poland (Kowalski and Wiercinski, 2009) showed that the $\mathrm{Hg}$ concentrations in cigarettes from these studies are almost equal to those of the present study. $\mathrm{Hg}$ in cigarettes was primarily found at $\mathrm{ppb}(\mu \mathrm{g} / \mathrm{g})$ concentration. $\mathrm{Hg}, \mathrm{Cd}$, and $\mathrm{Pb}$ concentrations in cigarettes from the selected countries in this study are almost equal to other studies. However, the $\mathrm{Cd}$ and $\mathrm{Pb}$ in cigarettes from Nigeria ranged from 5.90-7.94 $\mu \mathrm{g} / \mathrm{g}$ and 17.21-74.78 $\mu \mathrm{g} / \mathrm{g}$ (Benson et al., 2017), and are much higher than this study. Due to $\mathrm{Cd}$ and $\mathrm{Pb}$ 's high concentration, the Nigeria study showed that cancer health risk through inhalation was significant. In addition, cigarettes from Pakistan contained $\mathrm{Pb}$ at an average of $14.39 \mu \mathrm{g} / \mathrm{g}$ (Ajab et al., 2008), which is higher than the present study. $\mathrm{Cd}$ in cigarettes from Ethiopia (mean: $6.07 \mu \mathrm{g} / \mathrm{g}$ ) is also much higher than that of the present study (Engida and Chandravanshi, 2017).

\section{The correlations of nicotine with $\mathrm{Hg}, \mathrm{Cd}$, and $\mathrm{Pb}$ concentration in cigarettes}

There were significant positive correlations of nicotine with $\mathrm{Hg}$ and $\mathrm{Cd}$ concentrations in tobacco of cigarettes but not $\mathrm{Pb}$ (Fig. 5). The $r$ values of correlations of nicotine with $\mathrm{Hg}$ and $\mathrm{Cd}$ were 0.564 and 0.451 , respectively, and significant $(p<0.01)$, while the $r$-value correlation of nicotine with $\mathrm{Pb}$ was 0.008 . The results showed that the correlations between nicotine and these heavy metals are similar. The significant correlations of nicotine with $\mathrm{Hg}$ and $\mathrm{Cd}$ cause tobacco absorption from environmental factors. The mechanism within the tobacco plant for absorption of $\mathrm{Hg}$ and $\mathrm{Cd}$ from the environment such as soil, water, and fertilizer may be similar to that of nicotine. Other studies reported that the nicotine concentration in tobacco is closely correlated with the amount of nitrogen supplied (Wang et al., 2008). Nitrogen is present naturally in soils as nitrate ions, ammonium ions, and as a component of soil organic matter. Ammonium is readily converted to nitrate in all but the wettest and driest soils. Nitrogen generally produces the greatest growth response in plants of all fertilizer nutrients (Davies et al., 2001). On the other hand, the fertilizer may contain heavy metals like $\mathrm{As}, \mathrm{Cd}, \mathrm{Cr}, \mathrm{Ni}$, and $\mathrm{Hg}$, which can be transferred to tobacco and be correlated with nicotine concentration (O'Connor et al., 2015). Therefore, some percentage of $\mathrm{Hg}$ and $\mathrm{Cd}$ content in tobacco may have resulted from fertilizer application to the soil upon which the tobac- 
Q. Dinh et al.

Table 2. $\mathrm{Hg}, \mathrm{Cd}$, and $\mathrm{Pb}$ content in tobacco of marketed cigarettes from the selected countries.

\begin{tabular}{|c|c|c|c|c|}
\hline \multirow[b]{2}{*}{ Country } & \multicolumn{3}{|c|}{ Heavy metal concentration } & \multirow[b]{2}{*}{ References } \\
\hline & $\begin{array}{c}\mathrm{Hg}(\mathrm{ng} / \mathrm{g}) \\
\text { Mean } \pm \mathrm{SD} \\
(\mathrm{Min}-\max )\end{array}$ & $\begin{array}{c}\mathrm{Cd}(\mu \mathrm{g} / \mathrm{g}) \\
\text { Mean } \pm \mathrm{SD} \\
(\text { Min }-\max )\end{array}$ & $\begin{array}{c}\mathrm{Pb}(\mu \mathrm{g} / \mathrm{g}) \\
\mathrm{Mean} \pm \mathrm{SD} \\
(\mathrm{Min}-\mathrm{max})\end{array}$ & \\
\hline Korea & $20.89 \pm 3.48$ & $0.98 \pm 0.49$ & $4.41 \pm 0.46$ & This study \\
\hline$(\mathrm{n}=10)$ & $(16.74-28.31)$ & $(0.48-2.00)$ & $(0.78-7.18)$ & \\
\hline Vietnam & $27.23 \pm 6.69$ & $1.10 \pm 0.28$ & $1.60 \pm 1.10$ & This study \\
\hline$(\mathrm{n}=9)$ & $(19.35-43.98)$ & $(0.71-1.57)$ & $(0.42-3.43)$ & \\
\hline Japan & $18.38 \pm 2.60$ & $0.67 \pm 0.13$ & $0.43 \pm 0.17$ & This study \\
\hline$(\mathrm{n}=10)$ & $(15.47-22.87)$ & $(0.45-0.90)$ & $(0.13-0.66)$ & \\
\hline Indonesia & $14.19 \pm 2.77$ & $0.70 \pm 0.13$ & $1.58 \pm 0.90$ & This study \\
\hline$(\mathrm{n}=13)$ & $(10.32-18.97)$ & $(0.48-0.93)$ & $(0.13-14.51)$ & \\
\hline Taiwan & $19.67 \pm 4.11$ & $1.32 \pm 0.57$ & $0.61 \pm 0.14$ & This study \\
\hline$(n=6)$ & $(16.57-27.93)$ & $(0.89-2.32)$ & $(0.47-0.80)$ & \\
\hline Thailand & $27.80 \pm 1.06$ & $2.48 \pm 0.96$ & $0.98 \pm 0.27$ & This study \\
\hline$(n=4)$ & $(26.38-28.92)$ & $(1.85-3.89)$ & $(0.67-1.32)$ & \\
\hline UK & $17.72 \pm 1.92$ & $1.96 \pm 0.82$ & $5.60 \pm 0.86$ & This study \\
\hline$(\mathrm{n}=3)$ & $(15.60-19.35)$ & $(1.46-2.92)$ & $(4.62-6.21)$ & \\
\hline Belgium & $23.56 \pm 6.88$ & $1.80 \pm 0.69$ & $8.34 \pm 0.44$ & This study \\
\hline$(\mathrm{n}=3)$ & $(15.81-28.94)$ & $(1.29-2.58)$ & $(7.86-8.73)$ & \\
\hline Italy & $12.37 \pm 0.81$ & $0.65 \pm 0.15$ & $0.48 \pm 0.1$ & This study \\
\hline$(\mathrm{n}=3)$ & $(11.57-13.18)$ & $(0.47-0.74)$ & $(0.40-0.59)$ & \\
\hline Finland & $19.66 \pm 1.58$ & $1.36 \pm 0.18$ & $0.60 \pm 0.03$ & This study \\
\hline$(\mathrm{n}=3)$ & $(17.84-20.66)$ & $(1.22-1.56)$ & $(0.58-0.64)$ & \\
\hline France & $18.01 \pm 1.68$ & $1.68 \pm 0.71$ & $0.69 \pm 0.23$ & This study \\
\hline$(\mathrm{n}=3)$ & $(16.66-19.90)$ & $(1.10-2.47)$ & $(0.50-0.95)$ & \\
\hline Malaysia & NA & 3.05 & 0.08 & (Janaydeh et al., 2019) \\
\hline China & NA & 0.18 & 0.64 & (Yang et al., 2005) \\
\hline USA & $(17.9-24.9)$ & NA & NA & (Fresquez et al., 2015) \\
\hline Canada & 26.8 & NA & NA & (Hammond and O'Connor, 2008) \\
\hline USA & $13.0 \pm 1.3$ & NA & NA & (Panta et al., 2008) \\
\hline USA & $(20-21)$ & NA & NA & (Swani et al., 2009) \\
\hline Poland & $(6-74-10.56)$ & NA & NA & (Kowalski and Wiercinski, 2009) \\
\hline India & $<\mathrm{MDL}$ & 1.60 & 0.40 & (Dhaware et al., 2009) \\
\hline Jordan & NA & 2.67 & 2.64 & (Massadeh et al., 2005) \\
\hline Saudi Arabia & NA & 2.46 & 1.81 & (Ashraf, 2012) \\
\hline Ireland & NA & $(1.73-2.02)$ & $(0.38-1.16)$ & (Afridi et al., 2013) \\
\hline Pakistan & NA & 0.5 & 14.39 & (Ajab et al., 2008) \\
\hline Ethiopia & NA & 6.07 & 2.49 & (Adam Mekonnen and Bhagwan Singh, 2017) \\
\hline Iran & NA & 2.07 & 2.71 & (Pourkhabbaz and Pourkhabbaz, 2012) \\
\hline Nigeria & NA & $(5.90-7.94)$ & $(17.21-74.78)$ & (Benson et al., 2017) \\
\hline
\end{tabular}

$<$ MDL: below method detection limit, NA: not available.

co plant is cultivated. This probably explains the significant positive correlations of $\mathrm{Hg}$ and $\mathrm{Cd}$ with nicotine in the tobacco of cigarettes. Smokers are usually concerned about nicotine concentration in tobacco due to its stimulating nerve effects at different levels. Therefore, this study gives additional information on nicotine concentrations in tobacco of cigarettes due to their harmful effects on human health. The positive correlation may also indi- cate that the greater the nicotine concentration in tobacco, the higher the $\mathrm{Hg}$ and $\mathrm{Cd}$ levels, hence the greater the negative health effects on humans. Furthermore, other heavy metals and other tobacco types such as filterless cigarettes, chewing tobacco, and e-cigarettes also need to be studied further. 
Levels of some heavy metals in cigarettes from international markets
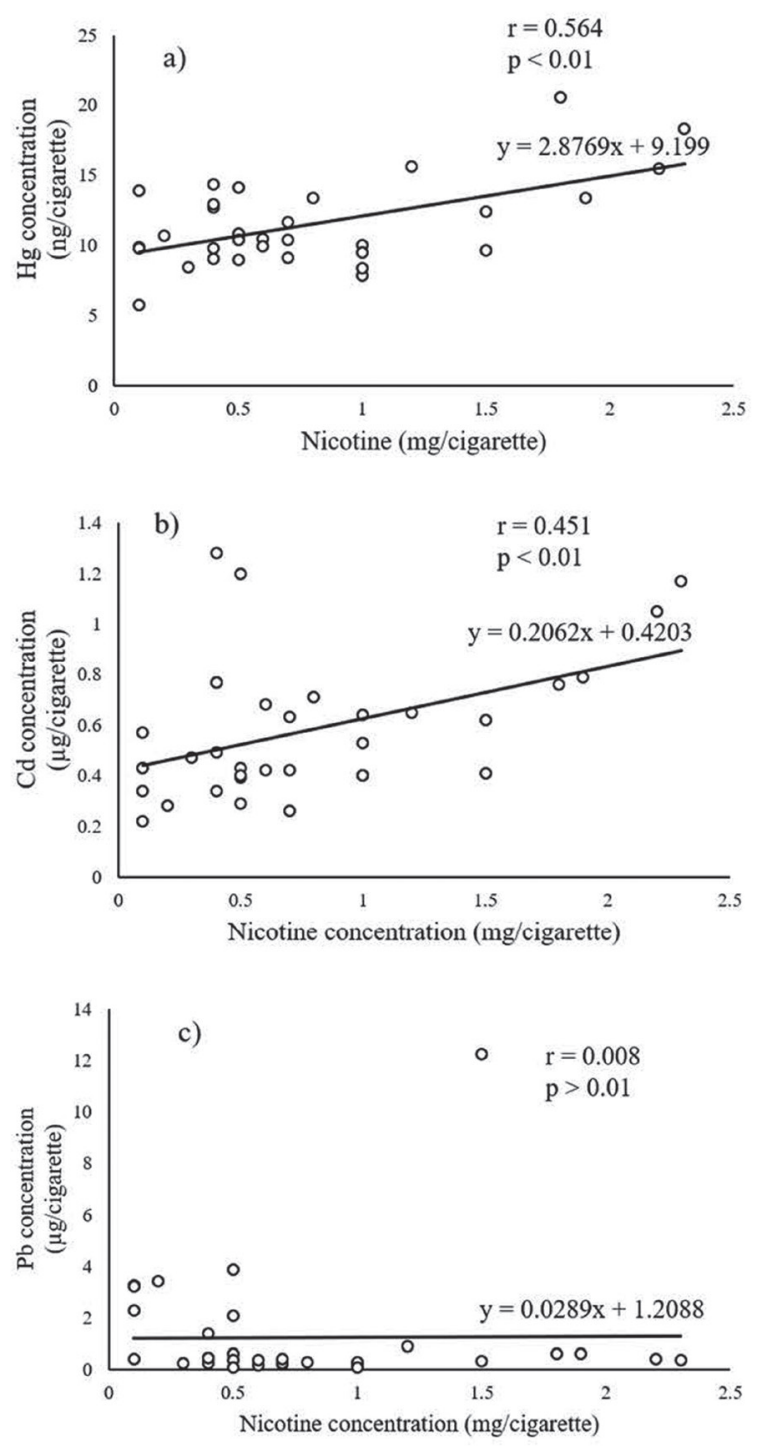

Fig. 5. The correlations of nicotine with $\mathrm{Hg}, \mathrm{Cd}$, and $\mathrm{Pb}$ in the cigarette. (a: correlation between nicotine and $\mathrm{Hg}, \mathrm{b}$ : correlation between nicotine and $\mathrm{Cd}$, c: correlation between nicotine and $\mathrm{Pb}$ ).

\section{The absorption ability of $\mathrm{Hg}, \mathrm{Cd}$, and $\mathrm{Pb}$ by cigarette filter}

In this study, $\mathrm{Hg}, \mathrm{Cd}$, and $\mathrm{Pb}$ concentrations in the filter were found at $0.26 \pm 0.24 \mathrm{ng} / \mathrm{g}$ cigarette, $0.35 \pm 0.25$ $\mu \mathrm{g} / \mathrm{g}$ cigarette and $0.97 \pm 0.92 \mu \mathrm{g} / \mathrm{g}$ cigarette (Table 1). The concentration of $\mathrm{Cd}$ remaining in the ash of cigarettes was $0.62 \pm 0.42 \mu \mathrm{g} / \mathrm{g}$ cigarette; meanwhile, $\mathrm{Pb}$ and $\mathrm{Hg}$ were not found $(<\mathrm{MDL})$. The results showed that the concentrations of $\mathrm{Hg}, \mathrm{Cd}$, and $\mathrm{Pb}$ in filters after smoking were higher than before smoking, indicating that the filter of cigarettes had abilities to absorb $\mathrm{Hg}, \mathrm{Cd}$, and $\mathrm{Pb}$ from the smoking process.

Basically, the filter of a cigarette is made of cellulose acetate plastic $(\mathrm{Ce})$. In recent days, there are several brands that add activated carbon to the cigarette filter $(\mathrm{Ce}-\mathrm{C})$. Therefore, we evaluated the difference of trapping ability between Ce filters (15) and Ce-C filters (14) using 29 cigarettes (Ce: Japan 5, Korea 2, and Vietnam 8; Ce-C: Japan 5, Korea 8, and Vietnam 1). The results of comparison of adsorption (trapping) ability of $\mathrm{Hg}, \mathrm{Cd}$, and $\mathrm{Pb}$ by the cigarette filter are indicated in Table 3 . The metal content of Ce-C $(\mathrm{Hg} 0.050 \pm 0.017 \mathrm{ng} /$ cigarette, $\mathrm{Cd}$ $0.010 \pm 0.005 \mu \mathrm{g} /$ cigarette and $\mathrm{Pb} 0.043 \pm 0.017 \mu \mathrm{g} /$ cigarette) was significantly higher than that of $\mathrm{Ce}(\mathrm{Hg} 0.024$ $\pm 0.013 \mathrm{ng} /$ cigarette, $\mathrm{Cd} 0.007 \pm 0.005 \mu \mathrm{g} /$ cigarette and $\mathrm{Pb} 0.018 \pm 0.014 \mu \mathrm{g} /$ cigarette), respectively. After smoking, the metal content of both $\mathrm{Ce}(\mathrm{Hg} 0.044 \pm 0.029 \mathrm{ng} /$ cigarette, $\mathrm{Cd} 0.036 \pm 0.017 \mu \mathrm{g} /$ cigarette and $\mathrm{Pb} 0.107 \pm$ $0.070 \mu \mathrm{g} /$ cigarette $)$ and $\mathrm{Ce}-\mathrm{C}(\mathrm{Hg} 0.053 \pm 0.023 \mathrm{ng} /$ cigarette, $\mathrm{Cd} 0.062 \pm 0.020 \mu \mathrm{g} /$ cigarette and $\mathrm{Pb} 0.197 \pm 0.114$ $\mu \mathrm{g} /$ cigarette) was found to be significant higher compared with before smoking (Ce: $\mathrm{Hg} 0.024 \pm 0.013 \mathrm{ng} /$ cigarette, $\mathrm{Cd} 0.007 \pm 0.005 \mu \mathrm{g} /$ cigarette and $\mathrm{Pb} 0.018 \pm 0.014 \mu \mathrm{g} /$ cigarette; Ce-C Hg $0.050 \pm 0.017$ ng/cigarette, Cd 0.010 $\pm 0.005 \mu \mathrm{g} /$ cigarette and $\mathrm{Pb} 0.043 \pm 0.017 \mu \mathrm{g} /$ cigarette) except for the $\mathrm{Hg}$ content of $\mathrm{Ce}-\mathrm{C}$. In addition, the metal contents in $\mathrm{Ce}-\mathrm{C}$ filters after smoking were also found to be higher compared with those of Ce filters, except for $\mathrm{Hg}$. The difference of metal content between $\mathrm{Ce}-\mathrm{C}$

Table 3. Metal content in filter $(\mu \mathrm{g} / \mathrm{cigarette})$ and the differences between the means of two groups.

\begin{tabular}{llccc}
\hline \multicolumn{1}{c}{ Filter } & & $\mathrm{Hg} \mathrm{ng} /$ cigarette & $\mathrm{Cd} \mu \mathrm{g} /$ cigarette & $\mathrm{Pb} \mu \mathrm{g} / \mathrm{cigarette}$ \\
\multirow{2}{*}{$\mathrm{Ce}$} & A: Before & $0.024 \pm 0.013$ & $0.007 \pm 0.005$ & $0.018 \pm 0.014$ \\
& C: After & $0.044 \pm 0.029^{*}$ & $0.036 \pm 0.017^{*}$ & $0.107 \pm 0.070^{*}$ \\
\hline \multirow{2}{*}{$\mathrm{Ce}-\mathrm{C}$} & B: Before & $0.050 \pm 0.017^{\#}$ & $0.010 \pm 0.005^{\#}$ & $0.043 \pm 0.017^{\#}$ \\
& D: After & $0.053 \pm 0.023$ & $0.062 \pm 0.020^{* \#}$ & $0.197 \pm 0.114^{* \#}$ \\
\hline
\end{tabular}

Ce: Filter that was made of cellulose acetate plastic only. Ce-C: Filter that was made of cellulose acetate plastic with activated carbon added. Data are represented as Mean $\pm \mathrm{SD}$.

*: $\mathrm{P}<0.01$ (A vs C, B vs D), \#: $\mathrm{P}<0.01(\mathrm{~A}$ vs B, C vs D). 
and $\mathrm{Ce}$ after smoking was identified as $\mathrm{Hg} 0.009 \mathrm{ng} / \mathrm{cig}$ arette, $\mathrm{Cd} 0.026 \mu \mathrm{g} /$ cigarette and $\mathrm{Pb} 0.09 \mu \mathrm{g} /$ cigarette. Because their levels in cigarettes were evaluated as $\mathrm{Hg}$ $12.3 \mathrm{ng} /$ cigarette, $\mathrm{Cd} 0.94 \mu \mathrm{g} /$ cigarette and $\mathrm{Pb} 1.62 \mu \mathrm{g} /$ cigarette, the ratio of trapped metals by filter was estimated as $\mathrm{Hg} 0.07 \%, \mathrm{Cd} 2.77 \%$ and $\mathrm{Pb} 5.56 \%$. Meanwhile, the trapping ratio of $\mathrm{Ce}-\mathrm{C}(\mathrm{Cd}: 5.53 \%, \mathrm{~Pb}: 5.41 \%)$ was higher than that of $\mathrm{Ce}(\mathrm{Cd}: 3.09 \%, \mathrm{~Pb}: 5.49 \%)$. On the other hand, $\mathrm{Hg}$ had lower absorption in both types of filters (Ce: $0.15 \%$, Ce-C: $0.02 \%)$. Even though $\mathrm{Ce}-\mathrm{C}$ has relatively higher trapping ability compared with $\mathrm{Ce}$, both filters did not have enough trapping ability for metals, especially $\mathrm{Hg}$.

As far as the authors know, this experiment was the first of its kind to be performed regarding $\mathrm{Hg}$. As for $\mathrm{Cd}$ and $\mathrm{Pb}$, although Ziarati et al. (2017) published that the ratios of $\mathrm{Cd}$ and $\mathrm{Pb}$ absorbed and trapped by filter were $116-234 \%$ and $112-198 \%$, the report did not show the detailed information. Therefore, it was difficult to understand the absorbing abilities of $\mathrm{Cd}$ and $\mathrm{Pb}$ from tobacco of cigarettes to smoke. From the results of this study, the authors considered that the filters could not absorb $\mathrm{Cd}, \mathrm{Pb}$ and $\mathrm{Hg}$ effectively. The experiment showed that $\mathrm{Pb}$ and $\mathrm{Hg}$ were not found in ash except that $\mathrm{Cd}$ remained at a small concentration $(0.62 \pm 0.42 \mu \mathrm{g} / \mathrm{g})$ in the ash. Therefore, almost all $\mathrm{Cd}, \mathrm{Pb}$, and $\mathrm{Hg}$ from tobacco and rolling paper also flowed with smoke when smoking. When a cigarette is smoked, the temperature in the cigarette's tip reaches a high value (up to $950^{\circ} \mathrm{C}$ ) (World Health Organization, 2019); at such a temperature, $\mathrm{Cd}, \mathrm{Pb}$, and $\mathrm{Hg}$ easily vaporize and become swept into a stream by smoke. Hg in particular easily vaporizes at high temperatures and this may explain why $\mathrm{Hg}$ absorption ability was the lowest. In $\mathrm{Pb}$ and $\mathrm{Cd}$ 's case, as we know, $\mathrm{Pb}$ has a density $\left(11.3 \mathrm{~g} / \mathrm{cm}^{3}\right)$ higher than that of $\mathrm{Cd}\left(8.65 \mathrm{~g} / \mathrm{cm}^{3}\right)$. That is perhaps the reason $\mathrm{Pb}$ was absorbed more effectively than $\mathrm{Cd}$ in the filter of cigarettes. In the designed experiment, the pump was kept running non-stop to keep all smoke flowing through the filter. Therefore, cigarette smoke contains harmful substances such as heavy metals that go to mainstream smoke. In fact, when humans smoke, the smoke of cigarettes separately becomes two flows that are mainstream and side-stream; meanwhile, both affect the active smoker and passive smoker in different levels that belong to smoking frequency and types of tobacco.

In conclusion, this study provides a comprehensive survey of $\mathrm{Hg}, \mathrm{Cd}$, and $\mathrm{Pb}$ in marketed cigarettes collected from Korea, Vietnam, Japan, Indonesia, Taiwan, Thailand, the UK, Belgium, Italy, Finland, and France with an objective assessment on an international scale. Accord- ing to the authors, this is the first research on the distribution concentration of $\mathrm{Hg}, \mathrm{Cd}$, and $\mathrm{Pb}$ in three parts of cigarettes separately: filter, tobacco, and rolling paper. One of the new findings of this research was that a significant correlation between $\mathrm{Hg}$ and $\mathrm{Cd}$ was found; and there is no correlation between each of these heavy metals and $\mathrm{Pb}$. In addition, the nicotine in cigarettes showed a significant positive correlation with $\mathrm{Cd}$ and $\mathrm{Hg}$. Even the lower metal trapping efficacy of active carbon additive filters was relatively higher as compared to those without active carbon, indicating the addition of activated carbon to the filter contributes to a minimal extent to the health of smokers. Notably, the ability to absorb Hg was not significantly different between these types of filters. The novelty of this study's key point was we found in the fact that the cigarette filter could not absorb $\mathrm{Cd}, \mathrm{Pb}$, and $\mathrm{Hg}$ well.

This study provides valuable data and information on $\mathrm{Hg}, \mathrm{Cd}$, and $\mathrm{Pb}$ in marketed cigarettes for tobacco companies, public health protection agencies, public health environment organizations, and the general smoking population concerning the effect of $\mathrm{Hg}, \mathrm{Cd}$, and $\mathrm{Pb}$ in marketed cigarettes.

\section{ACKNOWLEDGMENTS}

This study was supported by the Kumamoto Prefectural Government for International Postgraduate Scholarship for Research on Mercury and carried out in the Prefectural University of Kumamoto, Japan. The authors are thankful to The authors are thankful to Japan NUS company for their support to collect cigarettes, and also Dr. Jeffrey Stewart Morrow of Prefectural University of Kumamoto for his grammar checking.

Conflict of interest---- The authors declare that there is no conflict of interest.

\section{REFERENCES}

Adam Mekonnen, E. and Bhagwan Singh, C. (2017): Assessment of heavy metals in tobacco of cigarettes commonly sold in Ethiopia. Chem. Int., 3, 212-218.

Addai-Arhin, S., Novirsa, R., Jeong, H. H., Phan, Q. D., Hirota, N., Ishibashi, Y., Shiratsuchi, H. and Arizono, K. (2021). The human health risks assessment of mercury in soils and plantains from farms in selected artisanal and small-scale gold mining communities around Obuasi, Ghana. J. Appl. Toxicol., 1-16.

Afridi, H.I., Kazi, T.G., Talpur, F.N., Brabazon, D. and Naher, S. (2013): Estimation of toxic elements in the samples of different cigarettes and their impact on human health of Irish hypertensive consumers. Clin. Chim. Acta, 426, 51-57.

Agency for Toxic Substances and Disease Regitry (2019): Lead Toxicity Case Studies in Environmental Medicine. 
Levels of some heavy metals in cigarettes from international markets

Ajab, H., Yasmeen, S., Yaqub, A., Ajab, Z., Junaid, M., Siddique, M., Farooq, R. and Malik, S.A. (2008): Evaluation of trace metals in tobacco of local and imported cigarette brands used in Pakistan by spectrophotometer through microwave digestion. J. Toxicol. Sci., 33, 415-420.

Ashraf, M.W. (2012): Levels of heavy metals in popular cigarette brands and exposure to these metals via smoking. Sci. World J., 2012, 729430.

Badea, M., Luzardo, O.P., González-Antuña, A., Zumbado, M., Rogozea, L., Floroian, L., Alexandrescu, D., Moga, M., Gaman, L., Radoi, M., Boada, L.D. and Henríquez-Hernández, L.A. (2018): Body burden of toxic metals and rare earth elements in non-smokers, cigarette smokers and electronic cigarette users. Environ. Res., 166, 269-275.

Bai, X., Li, W., Wang, Y. and Ding, H. (2017): The distribution and occurrence of mercury in Chinese coals. Int. J. Coal Sci. Technol., 4, 172-182.

Benson, N.U., Anake, W.U., Adedapo, A.E., Fred-Ahmadu, O.H. and Ayejuyo, O.O. (2017): Toxic metals in cigarettes and human health risk assessment associated with inhalation exposure. Environ. Monit. Assess., 189, 619.

Davies, S., Reed, M. and O'Brien, S. (2001): Vermont Legislative Research Shop. The University of Vermont.

Dhaware, D., Deshpande, A., Khandekar, R.N. and Chowgule, R. (2009): Determination of toxic metals in Indian smokeless tobacco products. ScientificWorldJournal, 9, 1140-1147.

Engida, A.M. and Chandravanshi, B.S. (2017): Assessment of heavy metals in tobacco of cigarettes commonly sold in Ethiopia. Chem. Int., 3, 212-218.

Fresquez, M.R., Gonzalez-Jimenez, N., Gray, N., Watson, C.H. and Pappas, R.S. (2015): High-Throughput Determination of Mercury in Tobacco and Mainstream Smoke from Little Cigars. J. Anal. Toxicol., 39, 545-550.

Hammond, D. and O'Connor, R.J. (2008): Constituents in tobacco and smoke emissions from Canadian cigarettes. Tob. Control, 17 (Suppl 1), i24-i31.

Holbrook, B.D. (2016): The effects of nicotine on human fetal development. Birth Defects Res. C Embryo Today, 108, 181-192.

Janaydeh, M., Ismail, A., Zulkifli, S.Z. and Omar, H. (2019): Toxic heavy metal $(\mathrm{Pb}$ and $\mathrm{Cd})$ content in tobacco cigarette brands in Selangor state, Peninsular Malaysia. Environ. Monit. Assess., 191, 637.

Kowalski, R. and Wiercinski, J. (2009): Mercury content in smoke and tobacco from selected cigarette brands. Ecol. Chem. Eng. S, 16 (S2), 155-162.

Martin, T. (2019): Smoking Statistics From Around the World. Verywell Mind.

Massadeh, A.M., Alali, F.Q. and Jaradat, Q.M. (2005): Determination of cadmium and lead in different cigarette brands in Jordan. Environ. Monit. Assess., 104, 163-170.

Norvisa, R., Dinh, Q.P., Jeong, H., Fukushima, S., Ishibashi, Y.,
Wispriyono, B. and Ariznono, K. (2019): The evaluation of mercury contamination in upland rice paddy field around artisanal small-scale gold mining area, Lebaksitu, Indonesia. J. Environ. Saf., 10, 119-125.

O’Connor, R.J., Schneller, L.M., Caruso, R.V., Stephens, W.E., Li, Q., Yuan, J. and Fong, G.T. (2015): Toxic metal and nicotine content of cigarettes sold in China, 2009 and 2012. Tob. Control, 24 (Suppl 4), iv55-iv59.

Panta, Y.M., Qian, S., Cross, C.L. and Cizdziel, J.V. (2008): Mercury content of whole cigarettes, cigars and chewing tobacco packets using pyrolysis atomic absorption spectrometry with gold amalgamation. J. Anal. Appl. Pyrolysis, 83, 7-11.

Pourkhabbaz, A. and Pourkhabbaz, H. (2012): Investigation of toxic metals in the tobacco of different Iranian cigarette brands and related health issues. Iran. J. Basic Med. Sci., 15, 636-644.

Shaheen, N., Irfan, N.M., Khan, I.N., Islam, S., Islam, M.S. and Ahmed, M.K. (2016): Presence of heavy metals in fruits and vegetables: health risk implications in Bangladesh. Chemosphere, 152, 431-438.

Siqueira, L.M.; COMMITTEE ON SUBSTANCE USE AND PREVENTION. (2017): Nicotine and Tobacco as Substances of Abuse in Children and Adolescents. Pediatrics, 139, e20163436.

Institute of Medicine. (2001): Chapter 10. Tobacco Smoke and Toxicology. In: Clearing The Smoke, Assessing the science base for tobaco harm reduction (Stration, K., Shetty, P., Wallace, R. and Bondurant, S., eds.), National Academies Press, Washington.

Swani, K., Juud, C.D. and Orsini, J. (2009): Trace Metals Analysis of Legal and Counterfeit Cigarette Tobacco Samples Using Inductively Coupled Plasma Mass Spectrometry and Cold Vapor Atomic Absorption Spectrometry. Spectrosc. Lett., 42, 479-490.

United Nations Environment. (2019): Global Mercury assessment 2018 Key Findings. United Nations Environment Programe.

Wang, S.S., Shi, Q.M., Li, W.Q., Niu, J.F., Li, C.J. and Zhang, F.S. (2008): Nicotine concentration in leaves of flue-cured tobacco plants as affected by removal of the shoot apex and lateral buds. J. Integr. Plant Biol., 50, 958-964.

World Health Organization. (2019): Tobacco. Available at: https:// www.who.int/news-room/fact-sheets/detail/tobacco

Wu, H., Liu, Q., Ma, J., Liu, L., Qu, Y., Gong, Y., Yang, S. and Luo, T. (2020): Heavy Metal(loids) in typical Chinese tobacco-growing soils: Concentrations, influence factors and potential health risks. Chemosphere, 245, 125591.

Yang, G., Li, Z., Shi, H. and Wang, J. (2005): Study on the determination of heavy-metal ions in tobacco and tobacco additives by microwave digestion and HPLC with PAD detection. J. Anal. Chem., 60, 480-485.

Yurdakök, K. (2015): Lead, mercury, and cadmium in breast milk. J. Pediatr. Neonatal Individ. Med., 4, e040223.

Ziarati, P., Mousavi, Z. and Pashapour, S. (2017): Analysis of Heavy metals in Cigarette Tobacco. J. Med. Discov., 2, jmd16006. 